\title{
PENGEMBANGAN PENILAIAN SIKAP BERBASIS ANDROID UNTUK PEMBELAJARAN PENDIDIKAN AGAMA ISLAM
}

\section{Suwarno}

IAIN Takengon, Aceh, Indonesia

Email: fauzansuwarno@gmail.com

\begin{abstract}
Abstrak
Penilaian merupakan salah satu kemampuan yang harus dimiliki oleh guru, penilaian dalam kurikulum 2013 memiliki kerumitan yang lebih dibandingkan dengan sistem penilaian sebelumnya. Dalam kurikulum 2013 domain penilaian meliputi aspek kognitif, afektif, dan psikomotorik. Domain sikap merupakan domain yang banyak dikeluhkan oleh guru, termasuk guru pendidikan agama islam. Berangkat dari permasalahan tersebut peneliti ingin mengembangkan penilaian sikap berbasis android untuk memudahkan para guru dalam melakukan penilaian sikap. Tujuan dari penelitian ini adalah ingin mengetahui prosedur pengembangan penilaian sikap berbasis android, ingin mengetahui validitas dan kepraktisan penilaian sikap berbasis android yang dikembangkan. Metode penelitian yang digunakan dalam penelitian ini adalah penelitian pengembangan model ADDIE, yang terdiri dari lima langkah pengembangan, yakni; Analyze, Design, Development, Implementation, dan Evaluation. Teknik pengumpulan data dilakukan dengan wawancara, observasi dan angket. Analisa data menggunakan analisis diskriptif kualitatif untuk menganalisis data dari dari hasil wawancara dan observasi yang diperoleh pada saat studi pendahuluan, dan analisis kuantitatif digunakan untuk menganalisis data yang berasal dari angket validitas dan kepraktisan penilaian sikap hasil pengembangan. Hasil penelitian dari segi langkah penelitian pengembangan, penelitian ini sudah sesuai dengan prosedur penelitian pengemabangan model ADDIE, validitas penilaian sikap berbasis android yang dikembangkan sudah valid berdasarkan penilaian ahli IT dan ahli evaluasi yang memperoleh rata-rata skor 4,2, kepraktisan dalam penggunaan berdasarkan angket respon guru diperoleh skor rata-rata 4,02 dengan kriteria praktis.
\end{abstract}

Kata Kunci : pengembangan; penilaian sikap; android; pendidikan agama islam

Abstract
Assessment is one of the abilities that must be possessed by teachers, the
assessment in the 2013 curriculum has more complexity than the previous
assessment system. In the 2013 curriculum, the assessment domain includes
cognitive, affective, and psychomotor aspects. The attitude domain is a domain
that many teachers complain about, including Islamic religious education
teachers. Departing from these problems, researchers want to develop an
Android-based attitude assessment to make it easier for teachers to conduct
How to cite: $\quad$ Astuti, T. et.al (2021). Studi Keragaman Jenis Vegetasi di Kawasan Konservasi Cagar Alam Dolok
Tinggi Raja Kecamatan Dolok Merawa Kabupaten Simalungun. Syntax Literate: Jurnal Ilmiah
E-ISSN: $\quad$ Indonesia, 6(2).
Published by: $\quad$ Ridw-1398 Institute


attitude assessments. The purpose of this study was to find out the procedure for developing an Android-based attitude assessment, to find out the validity and practicality of the Android-based attitude assessment that was developed. The research method used in this research is ADDIE model development research, which consists of five development steps, namely; Analyze, Design, Development, Implementation, and Evaluation. Data collection techniques were carried out by interviews, observations and questionnaires. Data analysis used descriptive qualitative analysis to analyze data from the results of interviews and observations obtained during the preliminary study, and quantitative analysis was used to analyze data derived from questionnaires on the validity and practicality of developing attitude assessments. The results of the research in terms of development research steps, this research is in accordance with the ADDIE model development research procedure, the validity of the developed android-based attitude assessment is valid based on the assessment of IT experts and evaluation experts who get an average score of 4.2, practicality in use is based on a questionnaire. teacher response obtained an average score of 4.02 with practical criteria.

Keywords: development; attitude assessment; android; Islamic religious education

\section{Pendahuluan}

Pada tahun pelajaran 2014/2015 mulai diberlakukan kurikulum 2013 di seluruh Indonesia yang merupakan pembaharuan dan penyempurnaan kurikulum 2006. Sikapistik dasar Kurikulum 2013 adalah terletak pada pendekatan yang digunakan dalam pengembangan kurikulum tersebut. Kurikulum 2013 menekankan pendekatan saintifik pada jenjang Pendidikan dasar hingga menengah. Hal yang memberikan perbedaan mencolok antara Kurikulum 2013 dengan kurikulum sebelumnya adalah penekanan ranah pembelajaran. Kurikulum 2013 menekankan pada proses pendidikan yang holistik sehingga menyentuh pada cakupan yang lebih luas yaitu ranah kognitif, afektif, dan psikomotor. Kurikulum 2013 mengklasifikasikannya dalam empat kompetensi inti yaitu kompetensi sikap sosial, sikap spiritual, pengetahuan, dan keterampilan. Dengan demikian, maka potensi siswa selain dari domain kognitif juga dapat terpantau dan dikembangkan. Salah satu aspek yang mengalami per-kembangan dibanding kurikulum sebelum-nya adalah penilaian.

Penilaian merupakan salah satu kemampuan yang harus dimiliki oleh seorang guru karena hal tersebut merupakan bagian dari ciri profesionalismenya. Dengan hasil penilaian tersebut, seorang guru atau pendidik bisa menjadikannya sebagai bahan pertimbangan dalam membuat keputusan yang berkaitan dengan kegiatan pembelajaran. Istilah penilaian bukan merupakan istilah baru bagi insan yang bergerak pada lapangan Pendidikan dan pengajaran, dalam melaksanakan tugas profesinya, seorang guru tidak akan terlepas dari kegiatan penilaian. Kedudukan penilaian sangat penting bagi penunaian tugas keberhasilan melaksanakan tugasnya, yakni melaksanakan pembelajaran. Pada akhir program pendidikan, pengajaran ataupun pelatihan pada umumnya diadakan penilaian. Tujuannya untuk mengetahui apakah program pendidikan, pengajaran ataupun pelatihan itu telah dikuasai oleh pesertanya atau belum. 
Angka atau nilai tertentu biasanya dijadikan patokan untuk penguasaan program tersebut (Jihad \& Haris, 2012).

Penilaian memiliki peran besar dalam menentukan kesuksesan pendidikan. Penilaian yang baik memberikan dampak pada proses pembelajaran (Popham, 2009) dan menjadi rujukan untuk kebijakan selanjutnya (Mardapi, 2008). Ketepatan pemilihan metode penilaian akan sangat berpengaruh terhadap objektivitas dan validitas hasil penilaian yang ujungnya adalah informasi objektif dan valid atas kualitas pendidikan. Sebaliknya kesalahan dalam memilih dan menerapkan metode penilaian juga berimbas pada informasi yang tidak valid mengenai hasil belajar dan pendidikan.

Penilaian dalam Kurikulum 2013 dipandang memiliki kerumitan yang lebih dibandingkan dengan sistem penilaian pada kurikulum sebelumnya. Walaupun pemerintah telah mempersiapkan guru melalui berbagai pelatihan, namun masih banyak keluhan yang muncul di lapangan berkaitan dengan penilaian. Allen \& Friedman menyatakan bahwa yang paling kompleks dalam pembelajaran adalah integrasi pembelajaran berbagai domain yaitu kognitif, perilaku, dan perasaan (Allen \& Friedman, 2010). Menurut Retnawati salah satu aspek yang menjadi hambatan implementasi kurikulum 2013 adalah sistem penilaian yang rumit dan perlu waktu yang lama untuk menyusun laporanya (Retnawati, 2015).

Domain penilaian dalam Kurikulum 2013 meliputi domain spiritual, sikap sosial, pengetahuan, dan keterampilan. Secara lebih umum dapat dikategorikan menjadi tiga domain yaitu kognitif (pengetahuan), afektif (sikap sosial dan spiritual), dan psikomotor (keterampilan). Domain kognitif mencakup hasil yang berhubungan dengan aspek pengetahuan, pengertian, dan keterampilan berpikir (Bloom, 1956). Sikap menurut Fernandes merupakan kecenderungan seseorang terhadap objek yang berupa orang, konsep, ide, dan kelompok (Fernandes, 1984). Dengan demikian maka domain sikap meliputi perasaan, dan minat seseorang.

Domain sikap merupakan domain yang banyak dikeluhkan dalam proses penilaian Kurikulum 2013. Penilaian sikap (afektif) dalam berbagai mata pelajaran secara umum dapat dilakukan dalam kaitannya dengan berbagai objek sikap yang menurut Zakaria sebagai berikut:

Pertama, sikap terhadap mata pelajaran. Siswa perlu memiliki sikap positif terhadap mata pelajaran. Dengan sikap positif dalam diri siswa akan tumbuh dan berkembang minat belajar, akan lebih mudah diberi motivasi, dan akan lebih mudah menyerap materi pelajaran yang diajarkan. Oleh karena itu, guru perlu menilai tentang sikap siswa terhadap mata pelajaran yang diajarkannya.

Kedua, sikap terhadap guru mata pelajaran. Siswa perlu memiliki sikap positif terhadap guru, yang mengajar suatu mata pelajaran. Siswa yang tidak memiliki sikap positif terhadap guru, akan cenderung meng-abaikan hal-hal yang diajarkan. Dengan demikian, siswa yang memiliki sikap negatif terhadap guru pengajar akan sukar menyerap materi pelajaran yang diajarkan oleh guru tersebut.

Ketiga, sikap terhadap proses pembelajaran. Siswa juga perlu memiliki sikap positif terhadap proses pembelajaran yang berlangsung. Proses pembelajaran disini 
mencakup: suasana pembelajaran, strategi, metodologi, dan teknik pembelajaran yang digunakan. Tidak sedikit siswa yang merasa kecewa atau tidak puas dengan proses pembelajaran yang berlangsung, namun mereka tidak mempunyai keberanian untuk menya-takan. Akibatnya, mereka terpaksa mengikuti proses pembelajaran yang berlangsung dengan perasaan yang kurang nyaman. Hal ini dapat mempengaruhi terhadap penyerapan materi pelajarannya.

Keempat, sikap terhadap materi dari pokok-pokok bahasan yang ada. Siswa juga perlu memiliki sikap positif terhadap materi pelajaranyang diajarkan, yang menjadi kunci keberhasilan proses pembelajaran.

Kelima, sikap berhubungan dengan nilai-nilai tertentu yang ingin ditanamkan dalam diri siswa melalui materi suatu pokok bahasan. Misalnya, pengajaran pokok bahasan koperasi dalam mata pelajaran Pendidikan Agama Islam. Berhubungan dengan pokok bahasan ini, ada nilai spiritual tertentu yang relevan diajarkan dan diinternalisasikan dalam diri siswa (Zakaria, 2011). Seperti: kedisiplinan, menjalankan ibadah, toleransi, dan sebagainya. Dengan demikian, hal itu dapat untuk mengetahui hasil dari proses pembelajaran dan internalisasi nilai-nilai tersebut dalam diri siswa.

Menurut Andersen ada dua metode yang dapat digunakan untuk mengukur ranah afektif, yaitu metode observasi dan metode laporan diri. Penggunaan metode observasi berdasarkan pada asumsi bahwa karateristik afektif dapat dilihat dari perilaku atau perbuatan yang ditampilkan, reaksi psikologi, atau keduanya. Metode laporan diri berasumsi bahwa yang mengetahui keadaanafektif seseorang adalah dirinya sendiri. Namun, hal ini menuntut kejujuran dalam mengungkap sikapistik afektif diri sendiri (Anderson, 1981).

Sejak berlakunya kurikulum 2013 pada tahun pelajaran 2014/2015 hingga sekarang hampir semua guru merasa kebingungan dalam melakukan penilaian yang dituntut oleh Kurikulum 2013 terutama penilaian sikap. Berdasarkan hasil penelitian yang dilakukan oleh Intan Dwi Astuti di SD Muhamadiyah 24 Surakarta, menyatakan bahwa problematika guru dalam penilaian kurikulum 2013 di SD Muhammadiyah 24 Surakarta adalah meliputi perilaku siswa tidak terekam, permasalahan berikutnya yakni penilaian diri dirasa kurang valid, ada keberpihakan dan penilaian menjadi tidak objektif (Ningsih \& Sri Hartini, 2017). Hal senada juga diungkapkan Darna dalam penelitiannya yang berjudul kesulitan guru dalam mengembangkan penilaian sikap peserta didik di SDN 75 Locok Kab Enrekang, Darna menemukan dalam penelitiannya, ada tiga kesulitan domain yang di alami oleh guru di SDN 75 Locok Kab. Enrekang dalam melaksanakan penilaian sikap pada peserta didik yaitu yang pertama adalah sulitnya mengembangan instrument penilaian sikap yang terdiri dari menentukan spesifikasi instrumen, menulis instrumen penilaian sikap, yang kedua adalah sulitnya mengembangkan kriteria penilaian sikap dan yang ketiga adalah sulitnya mengembangkan teknik penilaian sikap yang terdiri dari observasi perilaku, penanyaan langsung dan laporan pribadi (Darna, 2016).

Selain dua kasus diatas terdapat kesulitan lain yang dialami guru dalam memberikan penilaian terhadap sikap siswa dalam proses pembelajaran berdasarkan 
kurikulum 2013 di SD Negeri 14 Banda Aceh adalah keterbatasan waktu, jumlah siswa yang banyak dalam satu kelas dan sulitnya mengarahkan siswa untuk menanamkan sikap yang baik sesuai dengan tujuan pembelajaran (Zuhera, Habibah, \& Mislinawati, 2017).

Kendala seperti kasus di atas juga terjadi di Madrasah Aliyah Swasta (MAS) AnNur Bener Meriah yang menjadi lokasi penelitian penulis. Dari survey awal yang peneliti lakukan pada bulan Desember tahun 2020, banyak guru yang belum memperoleh gambaran utuh tentang format penilaian sikap. Mulai dari muatan nilai sikap apa yang dikembangkan dalam kurikulum 2013, aspek penilaian sikap. Bahkan banyak guru yang belum memahami pengertian konsep sikap, ruang lingkup penilaian sikap dan pengembangan instrumen beserta cara penerapannya, lebih-lebih jika dikaitkan dengan implementasi penilaian kelas.

Dari permasalahan tersebut memunculkan ide baru pada peneliti untuk memudahkan guru dalam membuat laporan penilaian sikap, dengan menggunakan alat teknologi. Penggunaan teknologi dalam pendidikan sudah menjadi tuntutan untuk memperbaiki kualitas pendidikan di Indonesia. Perkembangan teknologi informasi dalam bidang pendidikan, berdampak pada munculnya jenis kegiatan yang berbasis teknologi, yaitu pendidikan yang berbasis elektronik. Perkembangan teknologi saat ini semakin pesat dimana dunia teknologi telah masuk pada seluruh kehidupan manusia. Yang salah satunya adalah penggunaan android.

Android merupakan sistem operasi open source yang artinya gratis dan bebas digunakan untuk para pengembang aplikasi, hal ini sangat memudahkan para developer atau pengembang aplikasi Android untuk membuat berbagai jenis aplikasi Android sesuai kehendaknya. Menurut Safaat android adalah sebuah sistem operasi untuk perangkat mobile berbasis linux yang mencakup sistem operasi, middleware dan aplikasi (Safaat, 2015).

Berangkat dari latar belakang masalah di atas maka penulis akan mengembangkan penilaian sikap berbasis android dengan tujuan untuk memudahkan guru dalam membuat laporan penilaian sikap, dan dapat memberikan serta memperbaiki inovasi pendidikan yang ada di sekolah. Tujuan dari penelitian ini adalah pertama untuk mengetahui prosedur pengembangan penilaia sikap berbasis android, kedua untuk mengetahui validitas penilaian sikap berbasis android hasil pengembangan, ketiga adalah mengetahui kepraktisan penialain sikap berbasis android hasil pengembangan.

\section{Metode Penelitian}

Metode penelitian yang digunakan dalam penelitian ini adalah jenis penelitian pengembangan. Penelitian pengembangan atau research and development (R\&D) adalah aktifitas riset dasar untuk mendapatkan informasi kebutuhan pengguna (needs assessment), kemudian dilanjutkan kegiatan pengembangan (development) untuk menghasilkan produk dan mengkaji keefektifan produk tersebut (Sugiyono, 2013). Penelitian dan pengembangan memiliki beberapa tahapan yang harus dilakukan. Tahapan pengembangan penilaian sikap berbasis Android ini dikembangkan dengan 
menggunakan model pengembangan ADDIE, yang terdiri dari lima langkah pengembangan, yakni; Analyze, Design, Development, Implementation, dan Evaluation (Tegeh \& Kirna, 2013).

Penelitian dilakukan di MAS An-nur Bener Meriah. Teknik pengumpulan data dilakukan dengan wawancara, observasi dan angket. Wawancara dilakukan pada para guru PAI untuk mendapatkan data tentang kendala tentang pelaksanaan penilaian sikap yang dilakukan. Observasi dilakukan untuk mendapatkan data tentang kebutuhan perangkat penilaian sikap, sedangkan angket dilakukan untuk mendapatkan data tentang kevalidan dan kepraktisan penilaian sikap berbasis android hasil pengembangan.

Teknik analisis data yang digunakan dalam penelitian ini adalah analisis diskriptif kualitatif dan anailisis kuantitatif. Analisis diskriptif kualitatif digunakan untuk menganalisis data dari dari hasil wawancara dan observasi yang diperoleh pada saat studi pendahuluan. Sedangkan analisis kuantitatif digunakan untuk menganalisis data yang berasal dari angket validitas dan kepraktisan penilaian sikap hasil pengembangan.

\section{Hasil dan Pembahasan}

Dalam pengembangan penilaian sikap berbasis android ini, peneliti menggunakan model ADDIE, dengan tahapan sebagai berikut:

\section{Analisis}

Tahap analisis peneliti lakukan pada saat studi pendahuluan untuk menemukan kendala guru dalam melakukan penilaian sikap dalam kurikulum 2013. Dalam tahap analisis ini peneliti melakukan analisis kebutuhan penilaian sikap berbasis android. Kegiatan dalam tahap analisis terdiri dari analisis kebutuhan guru, analisis kebutuhan siswa, analisis kebutuhan lembaga, serta analisis sarana prasara. Hasil dari tahapan diatas dijadikan dasar peneliti dalam merancang produk pengembangan penilaian sikap berbasis android yang sesuai. Berdasarkan analisis kebutuhan guru yang dilakukan dengan wawancara, guru meniginginkan adanya alat penilaian sikap yang praktis, hasil analisis sarana diketahui bahwa sekolah telah memiliki wifi dan semua guru menggunakan Handphone (HP) android sehingga memungkinkan untuk dikembangkan aplikasi penilaian sikap.

\section{Desain (Perancangan)}

Tahap perencanaan dilakukan untuk mendesain penilaian sikap berbasis android. Rancangan desain penilaian dengan tampilan sebagai berikut: 


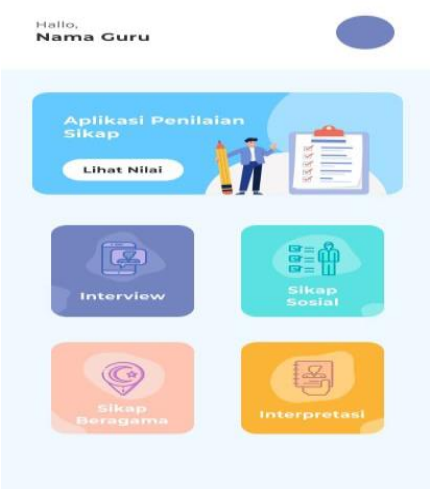

Gambar 1

Desain penilain sikap berbasis android

\section{Pengembangan (Developmen)}

Tahap pengembanagan merupakan proses mewujudkan desain yang sebelumnya telah dibuat kedalam bentuk nyata (fisik). Sehinga hasil dari pengembangan desain berupa produk penilaian sikap berbasis android, yang selanjutnya dilakukan validasi. Uji validasi ini dilakukan oleh dua ahli, yaitu ahli Teknologi Informasi (IT), dan ahli Penilaian Sikap. Setelah dilakukan uji validasi maka akan dilakukan revisi berdasarkan kritik dan saran yang diberikan oleh validator guna meningkatkan kualiatas produk hingga memiliki tingkat kevalidan yang sesuai dan layak untuk diuji cobakan di lapangan (sekolah).

Berdasarkan penilaian ahli IT diketahui bahwa terdapat 10 butir item pertanyaan untuk ahli IT. Dari seluruh item pertanyaan tersebut diperoleh skor sebesar 42. Skor tersebut kemudian dicari rata-ratanya dengan rumus:

$$
\mathrm{x}^{-}=\left(\sum \mathrm{x}\right) / \mathrm{n}
$$

Keterangan:

$\bar{x}=$ rata-rata penilaian kevalidan produk

$\Sigma x=$ jumlah skor penilaian kevalidan produk

$n=$ jumlah butir penilaian kevalidan produk

Maka $\bar{x}=42 / 10=4,2$

Rata-rata tersebut berada pada rentang interval 3,4 $\leq \mathrm{x}<4,2$ dengan kriteria valid. Dengan demikian dapat dinyatakan bahwa validitas penilaian sikap berbasis android hasil pengembangan merupakan aplikasi penilaian sikap yang valid berdasarkan penilaian ahli IT.

Kemudian hasil penilaian dari ahli evaluasi diketahui bahwa, ada 10 butir item pertanyaan untuk ahli evaluasi, ahli evaluasi melakukan validasi sebanyak 2 kali, hasil validasi pertama diketahui bahwa dari seluruh item pertanyaan tersebut diperoleh skor sebesar 30. Skor tersebut kemudian dicari rata-ratanya dengan rumus:

$$
\mathrm{x}^{-}=\left(\sum \mathrm{x}\right) / \mathrm{n}
$$

Keterangan:

$\bar{x}=$ rata-rata penilaian kevalidan produk

$\Sigma x=$ jumlah skor penilaian kevalidan produk 
$n=$ jumlah butir penilaian kevalidan produk

Maka $\bar{x}=30 /(10)=3,0$

Rata-rata tersebut berada pada rentang interval 2,7 $\leq \mathrm{x}<3,3$ dengan kriteria cukup valid. Dengan demikian dapat dinyatakan bahwa validitas penilaian sikap berbasis android hasil pengembangan berdasarkan penilaian ahli evaluasi adalah cukup valid. Hasil ini masih dibawah target yang seharusnya yaitu minimal penilaian sikap berbasis android yang dikembangkan bernilai valid. Saran dari ahli evaluasi agar periode penilaian jelas, dan kriteria penskoran harus jelas. Kemudian dilakukan revisi berdasarkan saran dari ahli evaluasi dengan tampilan hasil revisi sebagai berikut:

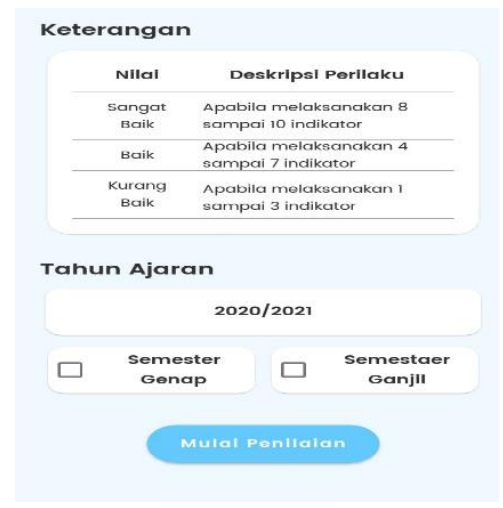

Gambar 2

Hasil revisi desain

Setelah dilakukan revisi sesuai saran ahli kemudian dilakukan lagi validasi ahli evaluasi tahap kedua. Hasil validasi ahli evaluasi tahap kedua diketahui bahwa dari seluruh item pertanyaan yang berjumlah 10 item diperoleh skor sebesar 42. Skor tersebut kemudian dicari rata-ratanya dengan rumus:

$$
\mathrm{x}^{-}=\left(\sum \mathrm{x}\right) / \mathrm{n}
$$

Keterangan:

$\bar{x}=$ rata-rata penilaian kevalidan produk

$\Sigma x=$ jumlah skor penilaian kevalidan produk

$n=$ jumlah butir penilaian kevalidan produk

Maka $\bar{x}=42 /(10)=4,2$

Rata-rata tersebut berada pada rentang interval $3,4 \leq \mathrm{x}<4,2$ dengan kriteria valid. Dengan demikian dapat dinyatakan bahwa validitas penilaian sikap berbasis android hasil pengembangan merupakan sudah berdasarkan penilaian ahli evaluasi.

Dengan demikian dapat dinyatakan bahwa berdasarkan penilaian ahli IT dan ahli evaluasi, penilaian sikap berbasis android hasil pengembangan sudah valid. Berikut tabel keseluruhan skor rata-rata validasi oleh ahli IT, dan Ahli Evaluasi penilaian sikap berbasis android 
Tabel 1

\section{Hasil Penilaian Oleh Ahli IT dan Ahli Evaluasi}

\begin{tabular}{llcccccc}
\hline \multirow{2}{*}{ No } & \multirow{2}{*}{ Penilai } & \multicolumn{2}{c}{ Skor } & \multicolumn{2}{c}{ Rata-rata skor } & \multicolumn{2}{c}{ Kriteria } \\
\cline { 3 - 8 } & & Tahap & Tahap & Tahap & Tahap & Tahap & Tahap \\
& & 1 & 2 & 1 & 2 & 1 & 2 \\
\hline 1 & Ahli IT & 42 & - & 4,2 & - & Valid & - \\
\hline 2 & $\begin{array}{l}\text { Ahli } \\
\text { Evaluasi }\end{array}$ & 30 & 42 & 3,0 & 4,2 & Valid & Valid \\
\hline
\end{tabular}

Berdasarkan tabel di atas maka dapat digambarkan diagramnya sebagai berikut:

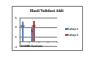

\section{Gambar 3 \\ Diagram hasil validasi ahli}

\section{Implementasi (Pelaksanaan)}

Tahap implementasi yaitu menguji produk. produk yang telah dibuat dan telah diuji kevalidannya kemudian diterapkan di sekolah. Kegiatan ini bertujuan untuk mengetahui seberapa praktis produk yang berupa aplikasi penilaian sikap dalam penerapannya di sekolah menurut respon guru PAI. Produk pengembangan ini memang harus diujicobakan secara langsung dalam pelaksanaan penilaian sikap. Ujicoba dilakukan di MAS An-Nur Bener Meriah dengan melibatkan 5 orang guru PAI. Dari ujicoba tersebut peneliti menyebarkan angket skala likerts berupa respon guru terhadap aplikasi penilaian sikap berbasis android hasil pengembangan untuk mengetahui kepraktisan produk yang dikembangkan. Angket respon guru berisi 20 butir pertanyaan, meliputi aspek tampilan berisi 5 pertanyaan, aspek penyajian materi 10 pertanyaan, dan aspek kemanfaatan 5 butir pertanyaan. Hasil angket respon guru disajikan pada tabel berikut: 
Suwarno

Tabel 2

Angket respon guru

\begin{tabular}{|c|c|c|c|c|}
\hline $\begin{array}{c}\text { Aspek } \\
\text { penilaian }\end{array}$ & $\begin{array}{l}\text { Item } \\
\text { nomer }\end{array}$ & Skor & Rata-rata & Kriteria \\
\hline \multirow{5}{*}{ Tampilan } & 1 & 25 & 4,1 & Praktis \\
\hline & 2 & 29 & 4,8 & Sangat praktis \\
\hline & 3 & 26 & 4,3 & Sangat praktis \\
\hline & 4 & 24 & 4,0 & Praktis \\
\hline & 5 & 23 & 3,8 & Praktis \\
\hline \multirow{10}{*}{$\begin{array}{l}\text { Penyajian } \\
\text { penilain }\end{array}$} & 6 & 28 & 4,6 & Sangat praktis \\
\hline & 7 & 24 & 4,0 & Praktis \\
\hline & 8 & 24 & 4,0 & Praktis \\
\hline & 9 & 19 & 3,1 & Cukup praktis \\
\hline & 10 & 23 & 3,8 & Praktis \\
\hline & 11 & 24 & 4,0 & Praktis \\
\hline & 12 & 24 & 4,0 & Praktis \\
\hline & 13 & 29 & 4,8 & Sangat praktis \\
\hline & 14 & 20 & 3,3 & Praktis \\
\hline & 15 & 23 & 3,8 & Praktis \\
\hline \multirow{5}{*}{ Aspek manfaat } & 16 & 24 & 4,0 & Praktis \\
\hline & 17 & 25 & 4,1 & Praktis \\
\hline & 18 & 25 & 4,1 & Praktis \\
\hline & 19 & 24 & 4,0 & Praktis \\
\hline & 20 & 20 & 3,3 & Praktis \\
\hline \multicolumn{2}{|c|}{ Tingkat pencapaian } & $\frac{483}{(20 \times 6)}$ & 4,02 & Praktis \\
\hline
\end{tabular}

Pada aspek tampilan mendapat skor 127 dengan rata-rata 4,2, berada pada rentang interval 3,2 $\leq \mathrm{x}<4,2$ dengan kriteria praktis. Aspek penyajian mendapat skor 238 dengan rata-rata 3,9, berada pada rentang interval $3,2 \leq \mathrm{x}<4,2$ dengan kriteria praktis. Kemudian aspek kemanfaatan mendapat skor 118 dengan rata-rata 3,9, berada pada rentang interval $3,2 \leq \mathrm{x}<4,2$ dengan kriteria praktis. 
Secara keseluruhan aspek tampilan, aspek penyajian, dan aspek kemanfaatan total skor mencapai 483 dengan rata-rata 4,02, skor tersebut berada pada rentang interval 3,2 $\leq \mathrm{x}<4,2$ dengan kriteria praktis. Dengan demikian dapat dinyatakan bahwa berdasarkan data di atas, penilaian sikap berbasis android hasil pengembangan merupakan instrumen penilaian sikap yang praktis. Berdasarkan data di atas maka dapat digambarkan dalam diagram berikut:

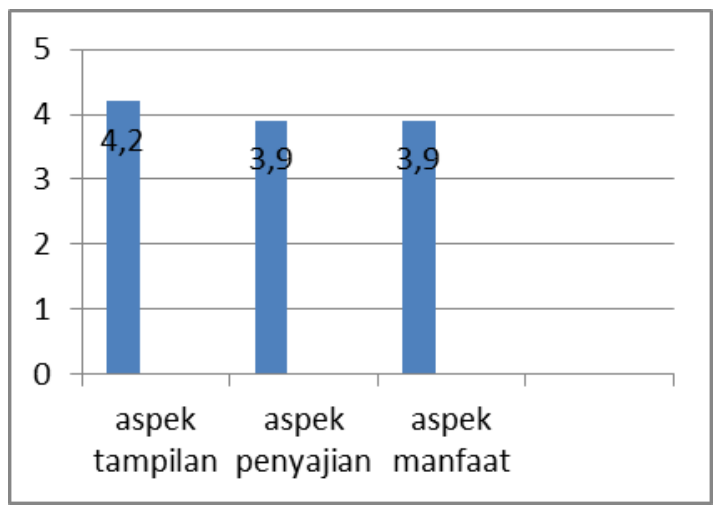

Gambar 4

\section{Diagram tingkat kepraktisan penilaian sikap berbasis android}

\section{Evaluasi}

Tahap pengembangan model ADDIE yang terakhir yaitu evaluasi. Tahap evaluasi terdiri dari dua macam, yaitu evaluasi formatif dan evaluasi sumatif. Evaluasi formatif sendiri merupakan evaluasi yang dilakukan selama proses pengembangan. Evaluasi formatif oleh validator (ahli teknologi informasi dan ahli evaluasi). Sedangkan evaluasi sumatif dilakukan pada akhir tahapan untuk mengetahui kepraktisan penilaian sikap hasil pengembangan, dalam evaluasi sumatif ini hasil dari ujicoba kepraktisan digunakan untuk mengetahui kekurangan dari aplikasi penilaian sikap yang dikembangkan, dan selanjutnya akan dilakukan revisi.

Prosedur pengembangan penilaian sikap berbasis android yang peneliti kembangkan diatas sudah sesuai dengan prosedur pengembangan ADDIE model, yakni dengan melalui 5 langkah penelitian. Pertama analisis kebutuhan utnuk melakukan penilaian sikap dari guru, kedua desain atau perancangan, pada tahap ini dilakukan rancangan produk penilaian sikap berbasis android, ketiga tahap pengembangan, yakni dengan membuat produk berupa aplikasi penilaian sikap berbasis android yang tervalidasi oleh ahli IT dan ahli penilaian sikap, keempat implementasi yaitu penerapan atau penggunaan, pada tahap ini dilakukan penggunaan aplikasi penilaian sikap oleh guru PAI di MAS An-Nur Bener Meriah, keliama adalah Evaluasi, evaluasi dilakukan untuk mengetahui kekurangan aplikasi penilaian sikap yang dikembangkan, dan selanjutnya dilakukan revisi. Sebagaimana diungkapkan oleh I Made Tegeh Model ini terdiri atas lima langkah, yaitu: (1) analisis (analyze), (2) perancangan (design), (3) pengembangan (development), (4) implementasi (implementation), dan (5) evaluasi (evaluation) (Tegeh, 2014). 


\section{Kesimpulan}

Berdasarkan hasil penelitian dan pembahasan yang dipaparkan pada bab 4 maka dapat disimpulkan bahwa, Prosedur pengembangan penilaian sikap berbasis android mengikuti model ADDIE, yang diawali dengan analisis, desain, developmen, implementasion dan evaluasi. Peneliti dalam hal ini yang mengembangkan penilaian sikap berbasis android telah mengikuti langkah pengembangan model ADDIE secara berurutan dan keseluruhan.

Validitas penilaian sikap berbasis android berdasarkan penilaian ahli IT dan ahli Evaluasi sudah memenuhi kriterai kevalidan dengan rentang 4,2 berada pada rentang skor $3,4 \leq \mathrm{x}<4,2$ dengan kriteria valid.

Kepraktisan penilaian sikap berbasis android dilakukan dengan cara menyebarkan angket respon guru, yang menyajikan aspek tampilan, aspek penyajian dan aspek kemanfaatan. Secara keseluruhan ketiga aspek tersebut mencapai skor 483 dengan ratarata 4,02, skor tersebut berada pada rentang interval 3,2 $\leq \mathrm{x}<4,2$ dengan kriteria praktis. 


\section{BIBLIOGRAFI}

Allen, K. N., \& Friedman, B. D. (2010). Affective learning: A taxonomy for teaching social work values. Journal of Social Work Values and Ethics, 7(2), 1-12.Google Scholar

Anderson, L. W. (1981). Assessing Affective Characteristic in the Schools. Boston: Allyn an dBacon. Inc. Google Scholar

Bloom, B. S. (1956). Taxonomy of educational objectives. Vol. 1: Cognitive domain. New York: McKay, 20(24), 1. Google Scholar

Darna, D. (2016). Kesulitan Guru dalam Mengembangkan Penilaian Sikap Peserta Didik di SDN 75 Locok Kab. Enrekang. Universitas Islam Negeri Alauddin Makassar. Google Scholar

Fernandes, H. J. X. (1984). Testing and measurement. Jakarta: Depdikbud. Google Scholar

Jihad, A., \& Haris, A. (2012). Evaluasi Pembelajaran Cetakan I. Yogyakarta. Multi Pressindo. Google Scholar

Mardapi, D. (2008). Teknik penyusunan instrumen tes dan nontes. Yogyakarta: Mitra Cendikia Press. Google Scholar

Ningsih, I. D. A., \& Sri Hartini, S. H. (2017). Problematika Guru dalam Penilaian Pembelajaran Kurikulum 2013 di SD Muhammadiyah 24 Surakarta Tahun 2016/2017. Universitas Muhammadiyah Surakarta. Google Scholar

Popham, W. J. (2009). Instruction that measures up: Successful teaching in the age of accountability. ASCD. Google Scholar

Retnawati, H. (2015). Hambatan guru matematika sekolah menengah pertama dalam menerapkan kurikulum baru. Jurnal Cakrawala Pendidikan, 34(3). Google Scholar

Safaat, N. (2015). Rancang Bangun Aplikasi Multiplatform. Informatika Bandung: Bandung. Google Scholar

Sugiyono, D. (2013). Metode penelitian pendidikan pendekatan kuantitatif, kualitatif dan R\&D. Google Scholar

Tegeh, I. M., \& Kirna, I. M. (2013). Pengembangan Bahan ajar metode penelitian pendidikan dengan addie model. Jurnal Ika, 11(1). Google Scholar

Zakaria, R. T. (2011). Penilaian Sikap. Jakarta: Pusat Penilaian Pendidikan: Badan Penelitian dan Pengembangan Pendidikan Nasional. Google Scholar 
Suwarno

Zuhera, Y., Habibah, S. H., \& Mislinawati, M. (2017). Kendala Guru Dalam Memberikan Penilaian Terhadap Sikap Siswa Dalam Prosespembelajaran Berdasarkan Kurikulum 2013 Di Sd Negeri 14 Banda Aceh. Jurnal Ilmiah Mahasiswa Pendidikan Guru Sekolah Dasar, 2(1). Google Scholar

\section{Copyright holder:}

Suwarno (2021)

\section{First publication right:}

Syntax Literate: Jurnal Ilmiah Indonesia

This article is licensed under:

(c) $\underset{\mathrm{BY}}{(\mathrm{i})} \mathrm{SA}$ 